\title{
Sales Structure Strategy in Bumiputera Muda LLC 1967 General Insurance Branch Lampung, Indonesia
}

\author{
M Yusuf S Barusman* \\ Faculty of Economic and Business, University of Bandar Lampung Jl. Zainal Abidin Pagar Alam No.26, \\ Labuhan Ratu, Kedaton, 35142, Bandar Lampung, Indonesia \\ Ferdinan \\ Faculty of Economic and Business, University of Bandar Lampung Jl. Zainal Abidin Pagar Alam No.26, \\ Labuhan Ratu, Kedaton, 35142, Bandar Lampung, Indonesia
}

\begin{abstract}
This study aims to analyze the position of Motor Vehicle Insurance products at this General Insurance Lampung Branch based on Product Life Cycle theory using a simple mathematical data analysis method. In addition, we also analyze the characteristics and objectives of marketing at each stage of his life which consists of factors of sales, profits, customer competitors, and marketing objectives achieved from these products. From the results of this analysis, a marketing strategy can be determined that is in accordance with its position in the Product Life Cycle. Judging from the theory of Product Life Cycle for Motor Vehicle Bumiputera Muda LLC 1967 General Insurance Lampung Branch is at the maturity stage. This is in accordance with the analysis of product performance taken from the data collected by this company in the form of a motor vehicle insurance policy that shows a growth rate of $24.35 \%$, receipt of operating profit from business activities of Motor Vehicle Insurance services in 2017 which is $5.86 \%$, and this increase indicates that the company's performance has increased and the average growth for 3 years is $0.29 \%$, and the analysis of the characteristics and objectives of product marketing at each stage of the product life cycle consists of sales, costs, profits, customers, competitors, and marketing objectives.
\end{abstract}

Keywords: Product Life Cycle, Motor Vehicle Insurance, Marketing Strategy

DOI: $10.7176 / \mathrm{JMCR} / 54-07$

Publication date:March $31^{\text {st }} 2019$

\section{Introduction}

Bumiputera Muda LLC 1967 General Insurance Lampung Branch based on data compiled has recorded total sales in 2017 for Motor Vehicle products of $24.35 \%$ from 2016, even though in 2016 there was a sales correction of ($15.22 \%$ ) from the previous year General 'motorkoe' package products are products that always experience an increase in percentage growth while 5 other products in 2016 have increased while in 2017 it has decreased and vice versa. The highest percentage of sales profit in 2017 is $38.22 \%$ with Mobilkoe General products and the lowest is $(-15.60 \%)$ which is a Special Motorkoe Package product. Compared to 2016 sales profit, the percentage of profit growth increased 5.86\% in 2017 even though there had been a decline in profit in 2015 of $(-5.28 \%)$.

Bumiputera Muda LLC 1967 General Insurance Lampung Branch strives to get customers both premium and claim insurance services. To achieve these conditions is not an easy thing. Bumiputera Muda LLC 1967 General Insurance Lampung Branch must establish strategies regularly so that it can bring towards achieving predetermined goals so as to meet the needs and desires of the target customers. Bumiputera Muda LLC 1967 General Insurance must have economic appeal. Creating a product that can be desired by consumers requires a maturity of strategies, namely marketing, finance, HR, and products that all these elements work together to create value for customers. So we need to know the position of the products based on the product life cycle theory, who are the productive consumers and competitors that can hinder the development of products, and what strategies have been established and how the right marketing strategy for product development by Bumiputera Muda LLC 1967 General Insurance Lampung Branch in Product Life Cycle.

Product life cycle is the life journey of a product starting from the product sold in the market until the product dies (Kasmir, 2015). The life cycle curve is generally divided into four stages (Kotler et al, 2012), namely:

1. Introduction stage

At this stage sales growth is slow; there is no profit due to the large costs of introducing the product

2. Stage of growth

Rapid market increase and large increase in profits

3. Stage of maturity or establishment

The decline in sales growth because products have been received by most potential buyers and stable profits will decline due to competition.

4. Stage of decline

Sales show a downward direction and thinning profits.

Kotler et al (2012) states that marketing strategies are defined as selecting target markets, determining 
competing positions, developing an effective marketing mix to achieve, and serving selected clients. Marketing strategies based on product life cycle concepts can be analyzed based on the performance of these products in generating profits. In addition, the characteristics related to sales, costs, types of customers, competitors, and marketing objectives are important factors to determine the marketing strategy.

To make it easier to describe the problems raised, the following framework is made:



Figure 1. Thinking Framework

\section{Methodology}

This research was conducted at PT. 1967 Bumiputera Muda General Insurance Lampung Branch, Pangeran Diponegoro Street No. 11 A Bandar Lampung. The time of the study was conducted from July to August 2018. This study used a descriptive qualitative research. Sugiyono (2011) stated that Descriptive Qualitative Research is a study that aims to provide a description of a phenomenon in detail to describe what happened. In carrying out this study, the types of data used are primary data and secondary data. The model used in this study is to analyze the characteristics and implications of the product life cycle strategy. Husein Umar (2013) stated that to find out the industrial conditions of a particular business can be through Product Life Cycle (PLC).

\section{Results and Discussion}

\subsection{Analysis of Product Portfolios with Boston Consulting Group (BCG) Matrix Products of Bumiputera} Muda LLC 1967 General Insurance Lampung Branch

The analysis carried out on the company's product was carried out with the following steps: First determine the market growth rate using sales data obtained from the company as follows: 
Table 1

Market Portfolio Growth Rate of Product PT. 1967 Bumiputera Muda General Insurance Lampung Branch Year 2015-2017

\begin{tabular}{|c|c|c|c|c|c|}
\hline \multirow{2}{*}{ Number } & \multirow{2}{*}{ Product } & \multicolumn{3}{|c|}{ Total Sales } & \multirow[t]{2}{*}{ Growth Rate } \\
\hline & & 2015 & 2016 & 2017 & \\
\hline \multirow[t]{2}{*}{1} & Fire Insurance & $862,793,777.00$ & $1,549,830,435.00$ & $958,445,262.00$ & $1,123,689,824.67$ \\
\hline & & - & $79.63 \%$ & $-38.16 \%$ & $13.82 \%$ \\
\hline \multirow[t]{2}{*}{2} & Motor Vehichle & $3,577,569,299$ & $3,033,106,324$ & $3,771,528,114$ & $3,460,734,579.00$ \\
\hline & & - & $-15.22 \%$ & $24.35 \%$ & $3.04 \%$ \\
\hline \multirow[t]{2}{*}{3} & Marine Cargo & $45,776,213.00$ & $6,843,020.00$ & $9,908,112.00$ & $20,842,448.33$ \\
\hline & & - & $-85.05 \%$ & $44.79 \%$ & $-13.42 \%$ \\
\hline \multirow[t]{2}{*}{4} & Marine Hull & - & - & - & - \\
\hline & & - & - & - & - \\
\hline \multirow[t]{2}{*}{5} & Aviation Hull & - & - & - & - \\
\hline & & - & - & - & - \\
\hline \multirow[t]{2}{*}{6} & Satellite & - & - & - & - \\
\hline & & - & - & - & - \\
\hline \multirow[t]{2}{*}{7} & Enggineering Insurance & - & - & - & - \\
\hline & & - & - & - & - \\
\hline \multirow[t]{2}{*}{8} & Profesional Liability Insurance & $348,579,500.00$ & $697,900,000.00$ & $778,527,500.00$ & $608,335,666.67$ \\
\hline & & - & $100.21 \%$ & $11.55 \%$ & $37.26 \%$ \\
\hline \multirow[t]{2}{*}{9} & Personal Accident & $2,768,308,450.00$ & $4,383,043,114.00$ & $1,745,711,530.00$ & $2,965,687,698.00$ \\
\hline & & - & $58.33 \%$ & $-60.17 \%$ & $-0.61 \%$ \\
\hline \multirow[t]{2}{*}{10} & Coverage Guarantee & $1,185,521,000.00$ & $1,720,489,000.00$ & $1,793,904,000.00$ & $1,566,638,000.00$ \\
\hline & & - & $45.13 \%$ & $4.27 \%$ & $16.46 \%$ \\
\hline \multirow[t]{2}{*}{11} & Miscellaneous Insurance & $16,891,500.00$ & $13,974,350.00$ & $11,918,750.00$ & $14,261,533.33$ \\
\hline & & - & $-17.27 \%$ & $-14.71 \%$ & $-10.66 \%$ \\
\hline \multirow[t]{2}{*}{12} & Health Insurance & $38,095,000.00$ & $25,955,075.00$ & $44,992,000.00$ & $36,347,358.33$ \\
\hline & & - & $-31.87 \%$ & $73.35 \%$ & $13.83 \%$ \\
\hline
\end{tabular}

The second step, determine the relative market share position in the insurance industry by using data obtained from Bumiputera Muda LLC 1967General Insurance and compare with the two main competing companies of each product in Lampung area.

Table 2

Relative Market Share Rate of Product Portfolio Bumiputera Muda LLC 1967 General Insurance Lampung Branch

\begin{tabular}{|c|c|c|c|c|c|}
\hline \multirow{2}{*}{ Number } & \multirow{2}{*}{ Product } & \multirow{2}{*}{$\begin{array}{l}\text { Sales } \\
2017\end{array}$} & \multicolumn{2}{|c|}{ Sales of 2 Competitors } & \multirow{2}{*}{$\begin{array}{l}\text { Market } \\
\text { Share }\end{array}$} \\
\hline & & & Competitor 1 & Competitor 2 & \\
\hline 1 & Fire Insurance & $958,445,262.00$ & $11,750,000,000$ & $8,645,000,000$ & 0.05 \\
\hline 2 & Motor Vehichle & $3,771,528,114$ & $1,133,400,000$ & $606,400,000$ & 2.17 \\
\hline 3 & Marine Cargo & $9,908,112.00$ & $345,000,000.00$ & $150,000,000.0 d$ & 0.02 \\
\hline 4 & Marine Hull & - & - & - & - \\
\hline 5 & Aviation Hull & - & - & - & - \\
\hline 6 & Satellite & - & - & - & - \\
\hline 7 & Enggineering Insurance & - & - & - & - \\
\hline 8 & Profesional Liability Insurance & $778,527,500.00$ & $65,750,000.00$ & $24,000,000.00$ & 8.67 \\
\hline 9 & Personal Accident & $1,745,711,530.00$ & $425,000,000.00$ & $320,000,000.00$ & 2.34 \\
\hline 10 & Coverage Guarantee & $1,793,904,000.00$ & $500,000,000.00$ & $412,000,000.00$ & 1.97 \\
\hline 11 & Miscellaneous Insurance & $11,918,750.00$ & $250,000,000.00$ & $145,000,000.00$ & 0.03 \\
\hline 12 & Health Insurance & $44,992,000.00$ & $750,000,000.00$ & $325,000,000.0 d$ & 0.04 \\
\hline
\end{tabular}

The third step is to plot the position of each product type of Bumiputera Muda LLC 1967 General Insurance Lampung Branch into Boston Consulting Group (BCG) matrix. To do the plot, the data in table 6 and table 7 are first combined into a resume table to facilitate identification and placement of product positions, as shown in the table below. 
Table 3

Portfolio Relative Growth and Market Share Rate Products of Bumiputera Muda LLC 1967 General Insurance Lampung Branch

\begin{tabular}{|c|l|c|c|}
\hline Number & \multicolumn{1}{|c|}{ Product } & $\begin{array}{c}\text { Growth } \\
\text { Percentage }\end{array}$ & Market Share \\
\hline 1 & Fire Insurance & $13.8 \%$ & 0.05 \\
2 & Motor Vehichle & $3.0 \%$ & 2.17 \\
3 & Marine Cargo & $-13.4 \%$ & 0.02 \\
\hline 4 & Marine Hull & - & - \\
\hline 5 & Aviation Hull & - & - \\
\hline 7 & Satellite & - & - \\
\hline 8 & Enggineering Insurance & - & 8.67 \\
\hline 9 & Personal Accident & $37.3 \%$ & 2.34 \\
\hline 11 & Coverage Guarantee & $-0.6 \%$ & 1.97 \\
\hline 12 & Miscellaneous Insurance & $16.5 \%$ & 0.03 \\
\hline
\end{tabular}

Based on the table above, a plot of the position of each product type of Bumiputera Muda LLC 1967 General Insurance Lampung Branch into Boston Consulting Group (BCG) matrix as follows:



Figure 2. BCG Portfolio Matrix

Bumiputera Muda LLC 1967 General Insurance Lampung Branch

Based on product mapping in the figure above about the product portfolio BCG Matrix Bumiputera Muda LLC 1967 General Insurance Lampung Branch, the results obtained are as follows:

Quadrant I or Question Mark, there are two products that are mapped in this position, namely fire insurance products and health insurance. Kotler et al (2007) argues that in the Question Mark quadrant a product that occupies this quadrant characterizes relatively high product growth rates, the level of product competition is still low, and the market share is still relatively low. Usually the company's cash needs are high and cash income is low. This quadrant is called a question mark because the company must decide whether to strengthen the product or not. The position of this quadrant gives the impression that the product lacks guaranteed profitability. When compared with the quadrant I Life Cycle Product theory, this is called the introduction stage. At this stage the product begins to be marketed in large quantities even though the sales volume is not yet high. Products that are sold are generally new products because they are still in the early stages; usually the costs incurred are high, especially advertising costs. Promotion must be aggressive and focus on the seller's brand. Besides that the product distribution is still limited and the profits obtained are still low.

Quadrant II or Star, there are two insurance products, namely professional liability insurance and guaranteed coverage. According to Kotler et al (2007) this quadrant is characterized by a very fast market growth position and a large market share, but on the other hand the position of competition occupies a high position. Star position is a position desired by all businesses because this position provides value for profitability in the long run. It's just that 
weakness in this position of business will spend a lot of investment in order to guarantee a competitive position. This means that this investment is intentionally used to innovate and strengthen strategies to maintain competitive positions and provide guarantees for profit growth. Products that occupy this quadrant must be careful because even though the cash inflow is quite high, it might not be enough to finance the very fast growth and cost of competition. Therefore the product must be seen at the level of the product life cycle. If the product has reached the mature level, the company must be careful in managing competition risk, do not let the investment issued is not comparable with the cash inflow obtained. When compared with the theory of Life Cycle Products (Swastha et al, 2012) quadrant I is called the growth stage. At this stage product sales and profits will increase and the public will already be familiar with the products being marketed, so the promotional efforts carried out are not as aggressive as the previous stage. Here competitors have begun to enter the market so that competition becomes tighter. Another way to expand and increase distribution is to reduce selling prices.

Quadrant III or Cash Cow, in this quadrant there are two products, namely Motor Vehicle and personal accident. According to Kotler (2001) the characteristics of its products are having a large market share compared to competitors, but low market growth, opportunities in this quadrant are still limited, and the market is not very attractive. This quadrant produces many benefits that can be used to invest in other fields because the market conditions are not attractive, so no important investment is needed to maintain the market. This awareness must be protected and maintained properly because a slight shift will have a large impact on market share due to low market growth. We must maintain as a market leader and owned market share. Profits are obtained from large sales volumes and the results can be used to support other businesses. When compared with the theory of this quadrant life cycle product at the maturity stage, product sales are still increasing and in the next stage remains. In this stage, price competition becomes so sharp that companies need to introduce their products with new models and advertising businesses usually begin to be upgraded to face competition.

IV Quadrant or Dog, there are two insurance products, namely marine cargo and Miscellaneous Insurance. According to Kotler (2007) this quadrant is a product that no longer has hope for life, meaning that this product no longer has superior competitiveness and a slow growth rate. As a result, the level of profitability tends to decline, even if it does not rule out the possibility of negative. This is because the product has no more attraction and competitiveness. Therefore the strategy adopted is investment, namely the strategy to close the product and invest in products that are still in the Star and Question Mark quadrants.

When compared with the fourth quadrant Life Cycle Product theory this is called the stage of setback. At this stage new items must have been marketed to replace old, old goods. Although competitors have started to decrease, supervision of costs has become very important because demand has declined considerably. If the old goods are not immediately replaced, the company can only operate on certain very limited markets.

\subsection{Product Development of Motor Vehicle Bumiputera Muda LLC 1967 General Insurance Lampung Branch}

Data on product development of Bumiputera Muda LLC 1967 General Insurance Lampung Branch is shown in the table below:

Table 4

Market Growth Rate of Motor Vehicle Product Portfolio

Bumiputera Muda LLC 1967 General Insurance Lampung Branch 2015-2017

\begin{tabular}{|c|c|c|c|c|c|}
\hline \multirow{2}{*}{ No. } & \multirow{2}{*}{ Product Name } & \multicolumn{3}{|c|}{ Sales (in rupiah) and Growth (\%) } & \multirow{2}{*}{ Average Growth } \\
\hline & & 2015 & 2016 & 2017 & \\
\hline 1 & Standard Motor Vehicle 4 Wheels & 1.886.661.748 & 1.272.317.051 & 1.900.957.684 & $1.686 .645 .494,33$ \\
\hline \multirow[t]{2}{*}{2} & General Motorkoe Package & 1.291.318.257 & 1.362.967.887 & 1.557.076.276 & $1.403 .787 .473,33$ \\
\hline & & - & $5,55 \%$ & $14,24 \%$ & $9,90 \%$ \\
\hline 3 & Special Motorkoe Package & 145.310 .458 & 159.478.375 & 130.043 .100 & $144.943 .977,67$ \\
\hline \multirow[t]{2}{*}{4} & Standard Motor 2 Wheels & 164.774.561 & 180.104.773 & 107.257 .557 & $150.712 .297,00$ \\
\hline & & - & $9,30 \%$ & $-40,45 \%$ & $-15,57 \%$ \\
\hline \multirow[t]{2}{*}{5} & Mobilkoe General & 48.724 .775 & 20.381 .288 & 25.754 .148 & $31.620 .070,33$ \\
\hline & & - & $-58,17 \%$ & $26,36 \%$ & $-15,90 \%$ \\
\hline 6 & Mobilkoe Special & 40.779 .500 & 37.856 .950 & 50.439 .349 & $43.025 .266,33$ \\
\hline
\end{tabular}

\subsection{Position Analysis of Motor Vehicle Products seen from the Product Life Cycle}

Data obtained from the annual financial statements of Bumiputera Muda LLC 1967 General Insurance Lampung 
Branch can be described as follows:

Table 5

Product Data of Bumiputera Muda LLC 1967 General Insurance Lampung Branch

\begin{tabular}{|c|c|c|c|c|}
\hline Number & Data & 2015 & 2016 & 2017 \\
\hline 1 & $\begin{array}{l}\text { Third Party Fund Insurance } \\
\text { Accentance for Motor Vehicle }\end{array}$ & $3,577,569,299$ & $3,033,106,324$ & $3,771,528,114$ \\
\hline 2 & Corporate profits & $926,317,000$ & $877,438,000$ & $928,898,000$ \\
\hline
\end{tabular}

Source: Annual Financial Report of Bumiputera Muda LLC 1967 General Insurance Lampung Branch

Table 6

Determination of Product Life Cycle

\begin{tabular}{|c|c|c|c|}
\hline Performance Size & $\begin{array}{c}\text { Performance of } \\
2017\end{array}$ & $\begin{array}{c}\text { Change compared to last } \\
\text { year }\end{array}$ & Growth rate \\
\hline $\begin{array}{c}\text { Third Party Fund Insurance } \\
\text { Acceptance for Motor Vehicle }\end{array}$ & $3,771,528,114$ & $24,35 \%$ & $4,56 \%$ \\
\hline Corporate profits & $928,898,000$ & $5,86 \%$ & $0,29 \%$ \\
\hline
\end{tabular}

1. Value of comparison of Fund receipts from Motor Vehicle Insurance customers in 2017 with 2016, which is $24.35 \%$. It is estimated that the value of Funds received from customers of Motor Vehicle Insurance increased significantly. This was driven by the steps of Bumiputera Muda LLC 1967 General Insurance Lampung Branch with a strategy adopted in choosing the target market, namely the multifarious marketing strategy (Differentiated Marketing). The multipurpose strategy is a strategy that offers several types of insurance products and identifies groups of buyers by dividing the market into 2 or more groups. In addition, the sale of vehicle insurance is mostly obtained because PT. Bumiputera Muda LLC 1967 General Insurance Lampung Branch has a cooperative relationship with several leasing companies and dealers in almost all Lampung Province regions.

2. Based on the average growth rate for 3 years, the growth value of fund receipts from Motor Vehicle insurance customers increased by a large $4.56 \%$. This increase shows that the level of public trust is increasing to insure their status at Bumiputera Muda LLC 1967 General Insurance.

3. The value of the comparison of operating income from the business activities of Motor Vehicle Insurance services in 2017 with 2016, which is $5.86 \%$. This increase shows that the company's performance has increased and the average growth for 3 years is $0.29 \%$. This shows that Bumiputera Muda LLC 1967 General Insurance Lampung Branch expanded its funding to a wider scope, conducted treasury and increased the ratio of insurance claims.

3.4 Position Analysis of Motor Vehicle Products by Analyzing the Characteristics and Implications of Product Strategies Based on Product Life Cycles

The product position is analyzed based on product characteristics and marketing objectives set by the company at each stage of the product life cycle. The characteristics analyzed are as follows:

a. Sales (in this case the number of Motor Vehicle Insurance policies)

Based on customer data collected by Bumiputera Muda LLC 1967 General Insurance Branch, which is based on the type of Insurance Motor Vehicle product recorded up to 2017, is 34,165 policies. This shows that in terms of sales there is an increase. This occurs because Bumiputera Muda LLC 1967 General Insurance Lampung branch is marketing intensively to get as many consumers from insurance customers as possible by utilizing the number of new vehicles launched and collaboration with dealers in Lampung Province.

b. Cost

Fees charged by Bumiputera Muda LLC 1967 General Insurance Lampung Branch to its customers is the average cost of subscriptions that are not too high or too low. Costs charged are limited to operational costs such as administration fees and policy making.

c. Profit

In the period 2015 to 2017 Bumiputera Muda LLC 1967 General Insurance Lampung Branch can generate profits every year.

Table 7

Obtaining Motor Vehicle Product Profit

\begin{tabular}{|c|c|c|c|}
\hline Data & 2015 & 2016 & 2017 \\
\hline Company Profit & $926,317,000$ & $877,438,000$ & $928,898,000$ \\
\hline
\end{tabular}

Based on the table above, it can be seen that the increase in profit per year has decreased in 2016 compared to 2015 , but has increased again in 2017 . So it can be concluded that the company is in an increasing profit 
condition even though it is unstable. This is because the expenses incurred in 2016 are relatively large. However, the burden that arises is not a burden that is directly related to the product, but rather the burdens related to the allowance for the elimination of productive assets, personnel, administration, and the public which are the result of company profits.

a. Customer

Customers of Bumiputera Muda LLC 1967 General Insurance Lampung Branch is mostly individual customer and is an initial user, namely customers who obtain information from innovator customers about Motor Vehicle products. The company can always get new customers every year and not lose old customers so that it has an impact on increasing the number of customers and income each year.

Customer type of the company is a floating customer and young executive who emphasizes the protection of newly purchased vehicles and the ease of obtaining a policy.

b. Competitor

Every year Bumiputera Muda LLC 1967 General Insurance Lampung Branch faces different competitors who tend to increase. There are several company names, among others, in the case of third party fund raising, Ramayana LLC Insurance and Bosowa LLC Insurance

c. Marketing Goals

The marketing objectives to be achieved by Bumiputera Muda LLC 1967 General Insurance Lampung Branch in accordance with the vision "Being a general insurance company that provides more value for stake holders" and 5 predetermined missions, then the company carried out a mass strategy, namely by opening office channels, conducting aggressive promotions as one of the strategies to increase public knowledge about its products in collaboration with local government institutions that have considerable vehicle assets. The purpose is intended to increase market share of a broad company.

Based on the description above relating to the analysis of product position at each stage of the cycle related to the characteristics of sales, costs, profits, customers, competitors, and marketing objectives, then conclusions can be drawn from the table below:

Table 8

Overview of the Characteristics of Each Product Lifecycle Stage

\begin{tabular}{|c|c|c|c|c|}
\hline Characteristics & Introduction & Growth & Maturity & Decline \\
\hline $\begin{array}{l}\text { Sales: } \\
\text { Low sales } \\
\text { Sales Increase Fast } \\
\text { Peak of Sales } \\
\text { Sales decline }\end{array}$ & $\checkmark$ & $\checkmark$ & $*$ & $\checkmark$ \\
\hline $\begin{array}{l}\text { Cost: } \\
\text { High Subscription Fee } \\
\text { Average subscription fee } \\
\text { Decreasing Subscription Fees } \\
\text { Low Subscription Fee }\end{array}$ & $\checkmark$ & $\checkmark$ & $*$ & $\checkmark$ \\
\hline $\begin{array}{l}\text { Profit: } \\
\text { Negative } \\
\text { Profit Increases } \\
\text { High Profit } \\
\text { Decreasing Profit }\end{array}$ & $\checkmark$ & $\checkmark$ & $*$ & $\checkmark$ \\
\hline $\begin{array}{l}\text { Customer: } \\
\text { Innovator } \\
\text { Initial Customer } \\
\text { Middle Majority } \\
\text { Late Use }\end{array}$ & $\checkmark$ & $\checkmark$ & $*$ & $\checkmark$ \\
\hline $\begin{array}{l}\text { Competitor: } \\
\text { a little } \\
\text { Increase Amount } \\
\text { Stable Amount Decreases } \\
\text { Decreasing Amount }\end{array}$ & $\checkmark$ & $\checkmark$ & $*$ & $\checkmark$ \\
\hline $\begin{array}{l}\text { Marketing Goals: } \\
\text { Creating Awareness and Desire for New Products } \\
\text { Maximizing the Market } \\
\text { Maximizing Profit by Staying Market Maintaining } \\
\text { Reducing Expenditures }\end{array}$ & $\checkmark$ & $\checkmark$ & $*$ & $\checkmark$ \\
\hline
\end{tabular}

* is the position of the product 
Based on the analysis of product performance taken from the data collected by PT. Lampung Branch Bumiputera Muda 1967 General Insurance in the form of a motor vehicle insurance policy which shows an average growth of $24.35 \%$, receipt of operating profit from business activities of Motor Vehicle Insurance services in 2017 with 2016 which is $5.86 \%$, and this increase indicates that company performance has increased and the average growth rate for 3 years is $0.29 \%$. Analysis of the characteristics and objectives of product marketing at each stage of the product life cycle consisting of sales (in this case the number of customers of motor vehicle insurance), costs, profits, customers, competitors, and marketing objectives can be concluded that Motor Vehicle products are at the maturity stage.

This analysis is in accordance with the product life cycle theory at the maturity stage proposed by Kotler; the maturity stage is characterized by the achievement of the highest point in the sale of the company. Normally this stage is the first stage in the product life cycle. This is because at this stage the fulfillment of the core needs of the product concerned remains. Therefore, most marketing strategies are aimed at products at this stage.

Sales at this stage are very sensitive to changes in the economy. The market is increasingly segmented, so that for each segment promotion is different from the others. Sales will slowly decline due to the incessant competitor entering.

\subsection{Analysis of the Marketing Strategy of Motor Vehicle Products at the Maturity Stage}

The stage of product maturity is characterized by the achievement of the highest point of sale of the company. Normally this stage is the longest stage in the product life cycle. This is because in the maturity stage of this product the core fulfillment of the needs of the related product still exists. Most of the products that are currently in this stage of maturity, therefore most marketing strategies are aimed at products at this stage. The creative marketing strategy used to extend the product life cycle is very sensitive to changes in the economy. Markets tend to be increasingly segmented, so that each segment needs different promotions from other segments. In Lajevardi et al (2015), marketing strategy such as promotion has a significant impact on the sales growth of any company. It was also noted that the use of direct distribution channel has a positive effect on the overall profitability of the firm. Entrepreneurs should engage in more marketing promotions by making use of the internet, radio, TV, billboards, and ensure their customers are reached wherever they are found.

In general, the stage of product maturity consists of three levels. The first level is called growth maturity, which is sales growth that begins to decrease due to distribution maturity. There are no new distribution channels that can be added. Then the second level is stable maturity, that is, sales tend to be flat due to market saturation. Some potential consumers have tried new products offered by the company. The third is decaying maturity, i.e. sales start declining and consumers begin to switch to other products or substitute products.

At least there are two main strategies that can be applied in the stage of product maturity, namely defensive strategy and offensive strategy.

1. Defensive Strategy

Defensive strategy aims to maintain market share from competitors and maintain product categories from product substitution attacks. The defensive strategy form is a marketing mix modification to get additional sales. This survival strategy focuses more on suppressing or reducing production costs and eliminating product weaknesses. In this strategy distributors play a very important role because the level of sales they get is influenced by the company's promotion efforts to encourage distributors to remain loyal to the company.

On the other hand, because the effectiveness of the promotion is reduced, the pricing of the product becomes another form of promotion. Although the promotion effort is aimed at maintaining product loyalty to distributors and consumers, the emphasis tends to be heavier on distributors. Although it is a good alternative strategy at the maturity stage, this strategy has a major weakness that is easily imitated by competitors, especially if what is done is increasing service activities, price cuts, and mass distribution. The benefits gained are not many because every action carried out by the company will get a reaction from the competitors.

2. Offensive Strategy

Offensive strategies focus more on change efforts to achieve a better level. The form of this offensive strategy can be modifying the market, namely by attracting a group of non-users (not users) and grabbing consumers from competitors. Another form of offensive strategy is product modification, namely changing product characteristics in such a way that it increasingly attracts consumers to buy by offering new benefits from products to consumers now to encourage more purchases and more frequent use (this business is often called as product re-launching). There are several alternative methods that can be used, namely:

a. Quality improvement strategies aim to improve product capabilities, such as product performance, speed, and product durability. They will be effective if the quality of the product can still be improved, consumers are sensitive to product quality, and consumers believe that later higher quality will provide higher benefits to consumers.

b. The feature improvement strategy is to add new features to the product. The advantage of this strategy is 
that it can improve the image of the company as a progressive market leader, provide free publicity for the company, can win the loyalty of certain market segments, encourage enthusiasm for distributors and salespeople, and can be done flexibly without additional costs. However, the biggest weakness is that this strategy is easy to imitate.

c. The model improvement strategy aims to increase the attractiveness of product aesthetics such as packaging, colors, models and so on. The advantage of this model is that it can create a distinctive identity in the market, and consumer loyalty to the brand. But this strategy also has problems other than those benefits. This strategy is difficult to know which groups like the new model and usually the new model will eliminate the old model that has been accepted (style loyalty) by consumers so that the company will risk losing consumers who really like the old model.

\section{Conclusion and Suggestion}

\subsection{Conclusion}

Based on the results of research from the Sales Turnover Strategy at Bumiputera Muda LLC 1967 General Insurance Branch Lampung, we can provide some conclusions as follows:

a. Judging from the theory of Product Life Cycle for Motor Vehicle Bumiputera Muda LLC 1967 General Insurance Lampung Branch is at the maturity stage.

b. The marketing strategy that is applied based on the product position according to Cycle's Product Life theory is as follows:

1. Improve product quality and increase product features or better design

2. The company enters new market segments and still maintains old market share

3. The company adds distribution coverage (branch opening) by entering a new distribution channel

4. Build the MV Insurance image which is a superior product with various privileges given

5. To attract consumers, the company decreases the temporary premium price

\subsection{Suggestion}

1. The company must begin to consider allocating funds to make the concept attract the attention of non-users, seize competing customers, enter new market segments through collaborating with finance and banking corporations that do not have insurance companies to increase competitiveness and increase profitability, such as cooperation with regional development banks and rural banks

2. The company must be more intensive in conducting research based on data experience for their products so that these products can be competitive again.

3. The company must carry out promotion through optimizing the recruitment of new agent members and strengthening its own agency network and utilizing Bumiputera 1912 agency network which is spread in every district to sub-districts in Lampung by placing a Supervisor in each Branch office and Unit joint life insurance Bumiputera 1912.

\section{References}

Armstrong, G., \& Kotler, P. (2007). Marketing: An introduction. Upper Saddle River, N.J: Pearson Prentice Hall. Basu, Swastha DH., Irawan. (2012). 2nd Edition Modern Marketing Management.Yogyakarta: Liberty Offset.

Husein Umar. 2013. Research Methods for Thesis and Thesis. Rajawali. Jakarta.

Kasmir. 2015. Analysis of Financial Statements. PT Raja Grafindo Persada. Jakarta.

Kotler, Philip. 2001. Marketing Management: Analysis, Planning, Implementation, and Control. Jakarta: PT. Prehallindo.

Kotler, P. and Keller, K. (2012). Marketing management. Upper Saddle River, N.J.: Prentice Hall.

Lajevardi, M., \& Faez, A. (2015). Marketing and Entrepreneurship: Relationship Between Marketing Strategies, Entrepreneurial Development, Sale Growth and Corporate Profitability. Journal Of Marketing and Consumer Research. Vol 17. 1-9.

Sugiyono. 2011. Qualitative Quantitative Research Methods. Alfabetta Publisher. Bandung. 